九州大学学術情報リポジトリ

Kyushu University Institutional Repository

Effects of High Temperature on Photosynthesis, Membrane Lipid Peroxidation and Osmotic Adjustment in Four Rhododendron Species

GENG, Xing-Min

Department of Landscape Plant, Nanjing Forestry University

YANG, Qiu-Yu

Department of Landscape Plant, Nanjing Forestry University

YUE, Yuan

Department of Landscape Plant, Nanjing Forestry University

OZAKI, Yukio

Laboratory of Horticultural Science, Department of Bioresource Sciences, Faculty of Agriculture, Kyushu University

https://doi.org/10.5109/2231631

出版情報：九州大学大学院農学研究院紀要. 64 (1)，pp.33-38，2019-02-28. Faculty of Agriculture， Kyushu University

バージョン :

権利関係 : 


\title{
Effects of High Temperature on Photosynthesis, Membrane Lipid Peroxidation and Osmotic Adjustment in Four Rhododendron Species
}

\author{
Xing-Min GENG ${ }^{1 *}$, Qiu-Yu YANG ${ }^{1}$, Yuan YUE ${ }^{1}$ and Yukio OZAKI \\ Laboratory of Horticultural Science, Department of Bioresource Sciences, \\ Faculty of Agriculture, Kyushu University, Fukuoka 819-0395, Japan \\ (Received October 31, 2018 and accepted November 12, 2018)
}

\begin{abstract}
In order to make clear the response mechanism of Rhododendron species to high temperature, twoyear-old seedlings of $R$. fortunei, $R$. ovatum, $R$. simsii and $R$. mariesii were heat-stressed at $42^{\circ} \mathrm{C} / 30^{\circ} \mathrm{C}$ (day/night) for $24 \mathrm{~h}$. Four Rhododendron species under heat stress showed significant differences in heat injury indices (HII), and R. fortunei was more sensitive to high temperature than the other three species. The lipid peroxidation of $R$. fortunei seedling was most serious indicated by malondialdehyde (MDA), which could be related to the significant decrease of superoxide dismutase (SOD) activity in $R$. fortunei seedlings. In the other three heat-resistant species, the content of soluble proteins and SOD activity increased under heat stress. The accumulation of proline and soluble sugars was found in greater heatresistant species, which could alleviate osmotic stress of rhododendron seedlings under high temperature. Net photosynthesis $\left(\mathrm{P}_{\mathrm{N}}\right)$ rates for four species were inhibited at different levels due to heat stress, but reduction proportion of $\mathrm{P}_{\mathrm{N}}$ for $R$. fortune $i$ was highest due to mainly nonstomatal factors.
\end{abstract}

Key words: compatible osmolytes, heat stress, photoinhibition, Rhododendron, superoxide dismutase

\section{INTRODUCTION}

In order to cope with heat stress, plants implement various mechanisms, including maintenance of membrane stability, scavenging of reactive oxygen species (ROS), accumulation and adjustment of compatible solutes, induction of differentially accumulated proteins or up-regulation of some protein. ROS production can be accelerated by heat stress (Larkindale and Knight, 2002) and other environmental stresses (Cruz de Carvalho, 2008). Excessive ROS causes oxidative stress, leading to lipid peroxidation, protein degradation, enzyme inactivation, and DNA damage (Apel and Hirt, 2004; Kai et al., 2012). ROS toxicity can be alleviated by ROS-scavenging enzymes include both enzymatic antioxidants such as superoxide dismutase (SOD) and other non-enzymatic antioxidants. And keeping the steady-state level of ROS enables ROS to act as signaling molecules to control and regulate plant growth, development, contributes to the responses to the environmental stresses (Mittler et al., 2004; Mittler, 2017).

Under the stresses, different plant species may accumulate a variety of osmolytes such as sugars and sugar alcohols (polyols), proline, and tertiary sulphonium compounds (Wahid et al., 2007). Accumulation of proline may contribute to enhanced stress tolerance of plants (Kaushal et al., 2011; Wilson et al., 2014) by protecting some vital enzymes related to carbon and oxidative metabolism (Kaushal et al., 2011). Supplementation with proline considerably reduced $\mathrm{H}_{2} \mathrm{O}_{2}$ production and showed decrease in oxidative injury coupled to elevated levels of antioxidants in sugarcane (Rasheed et al., 2011). But proline that accumulated in plants subjected

\footnotetext{
Department of Landscape Plant, Nanjing Forestry University, Nanjing 210037, Jiangsu Province, People's Republic of China;

* Corresponding author (E-mail: xmgeng76@163.com)
}

to drought did not accumulate in Arabidopsis during a combination of drought and heat stress, sucrose replaces proline in plants as the major osmoprotectant (Rizhsky et al., 2004). Similarly, accumulation of soluble sugars under heat stress has been reported in sugarcane, which entails great implications for heat tolerance (Wahid and Close, 2007). Sugars may protect the chloroplast membranes partially or completely (Santarius, 1973).

Net photosynthesis $\left(\mathrm{P}_{\mathrm{N}}\right)$, in particular, is one of the most heat-sensitive processes governing plant growth (Bjorkman et al., 1980). And $\mathrm{P}_{\mathrm{N}}$ has been shown to correlate with heat tolerance of Rhododendron plants (Ranney et al., 1995), a combination of stomatal and nonstomatal limitations on $\mathrm{P}_{\mathrm{N}}$ at high temperatures resulted in difference in heat tolerance. Photoinhibition in evergreen leaves can be brought about by oxidative damage to PSII by ROS (Adams III et al., 2004). However, ROS has been suggested that it does not result in photodamage directly, but inhibits the repair of photodamaged PSII by suppressing the synthesis of PSII proteins in chloroplasts (Murata et al., 2007; Takahashi and Murata, 2008).

The genus Rhododendron ( \pm 1000 species) is divided into eight subgenera (Chamberlain et al., 1996). Wild Rhododendron species are most distributed in high mountains, they favor cold environmental conditions, and high temperature has been the primary obstacle to cultivation and propagation. Therefore, the research on mechanism of heat tolerance and possible strategies for improving heat tolerance is imperative. In this present research, photoinhibition, the accumulation of osmolytes, the production and scavenging of ROS were investigated to screen the physiological indices, which may be related to heat tolerance of Rhododendron seedlings. 


\section{MATERIALS AND METHODS}

\section{Plant materials and heat stress}

Two-year-old seedlings of four Rhododendron species including $R$. fortunei, $R$. ovatum, R. simsii and $R$. mariesii were used as plant materials. According to the method of heat stress as reported in previously (Gu et al., 2016), the seedlings were heat-stressed at $42^{\circ} \mathrm{C} / 30^{\circ} \mathrm{C}$ (day/night) for $24 \mathrm{~h}$ and light intensity of $4000 \mathrm{LX} / 0 \mathrm{LX}$ (day/night). As a control, the other potted plants were placed at $28^{\circ} \mathrm{C} / 18^{\circ} \mathrm{C}$ (day/night). After the heat stress experiments, the plants were moved back to the greenhouse of $23-33^{\circ} \mathrm{C}$.

The plants were continuously observed every day, and the injury index was recorded on the first day after heat stress. The extent of heat injury was divided six grades, 0: no heat injury; 1: yellowing or scorching of 1-2 leaves; 2: yellowing or scorching of 2-4 leaves, one leaf wither; 3: 2 leaves wither; 4: more than 2 leaves wither; 5: the whole plant died. The heat injury index was calculated according to the following formula: Heat injury index $=(\Sigma$ injury grades $\times$ corresponding number of seedlings) / the highest grade $\times$ total number of seedlings

\section{Determination of other physiological indices}

Leaves were collected from heat-stressed and control seedlings on the fifth day after heat stress, these samples were stored at $-80^{\circ} \mathrm{C}$ for the determination of proline, MDA, soluble proteins and SOD activity. Proline was determined by the specific colorimetric method at $515 \mathrm{~nm}$, which measures the red and stable product from reaction of proline and hydrindantin dehydrate under acidic condition. Malondialldehyde (MDA) was determined by the method of thiobarbituric acid (TBA) as previously described (Geng et al., 2009). The content of soluble proteins was determined according to the method of Bradford (1976) using bovine serum albumin as standard.

Samples were prepared for SOD enzyme analyses by homogenizing $0.3 \mathrm{~g}$ of frozen samples in $5 \mathrm{ml}$ of an icecold $50 \mathrm{mM}$ sodium phosphate buffer $(\mathrm{pH} 7.8)$. The extract was centrifuged at $4^{\circ} \mathrm{C}$ for $20 \mathrm{~min}$ at $12500 / \mathrm{g}$. The supernatant was then used for enzyme assays. Total activity of SOD in the extract was determined by measuring the inhibition in the photochemical reduction of nitroblue tetrazolium (NBT). One enzyme unit was defined as the amount of enzyme required to cause $50 \%$ inhibition of the rate of NBT reduction measured at $560 \mathrm{~nm}$.

Glucose was used to prepare a standard solution to make a calibration curve for determination of soluble sugar contents. $0.3 \mathrm{~g}$ of leaves was placed in $20 \mathrm{~mL}$ distilled water. After boiling for $30 \mathrm{~min}$ followed by cooling to room temperature and filtration with filter paper, the sample filtrates were collected. Dilute anthrone sulfuric acid reagent $(5 \mathrm{~mL})$ was mixed with each standard or sample solution $(0.1 \mathrm{~mL})$, immediately placed in a boiling water bath for $1 \mathrm{~min}$, and then cooled to room temperature. The absorbance at $630 \mathrm{~nm}$ was measured.

\section{Photosynthesis measurement}

$\mathrm{P}_{\mathrm{N}}$, stomatal conductance (Gs), intercellular $\mathrm{CO}_{2}$ concenrtration $(\mathrm{Ci})$ and transpiration rate $(\mathrm{Tr})$ were measured with LI-6400 (Licor company, America). The values reported were the mean of two measurements per plant taken on marked leaves of three different plants. The measurements were taken during the first day and fifth day after heat stress between 10:00 AM and 11:00 PM.

Statistical analyses were carried out by using SPSS17.0 software. The Duncan's multiple range test was applied to test the significance in differences among treatments $(\mathrm{P}>0.05)$.

\section{RESULTS}

\section{Morphological symptoms of heat injury}

To compare heat tolerance of four $R$. species and observe the differences of morphological symptoms in responses to heat stress, the rhododendron seedlings were exposed to high temperature of $42^{\circ} \mathrm{C} / 30^{\circ} \mathrm{C}$ (day/ night) for $24 \mathrm{~h}$. The results showed phenotypic appearances of four $R$. species under heat stress were distinguishable (Fig. 1). After heat stress, R. fortunei seedlings exhibited significant heat injury symptoms related to chlorosis of leaf apex, leaf rolling up. $R$. simsii leaves slightly wilted after heat stress, there were a few middle leaves appearing etiolated symptom, but did not aggravate in the next few days. Some filemot spots appeared on the lower old leaves of $R$. ovatum, central functional leaf margin turned red, and new leaves curled. Heat injury symptoms on $R$. mariesii seedlings occurred mainly in the newly folded leaf buds of tip stem, the leaf apex scorched and central functional leaves exhibited red block.

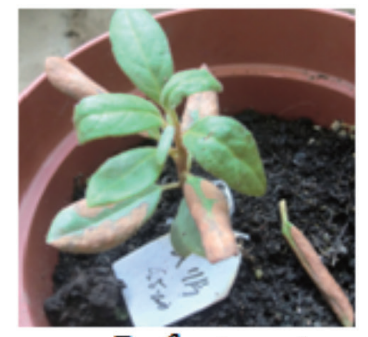

R. fortunei

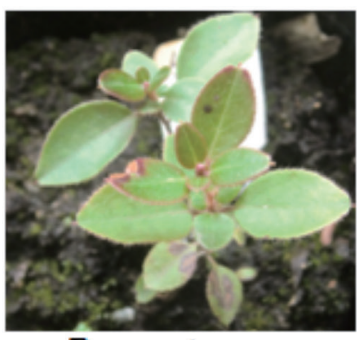

R. ovatum

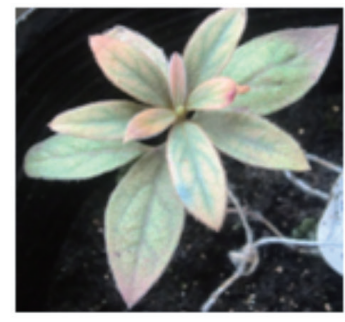

R. simsii

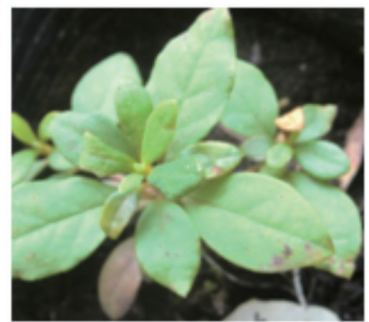

R. mariesii

Fig. 1. Heat injury symptoms of four Rhododendron species on the first day after heat stress. 
Four species under test showed significant difference in heat injury indices (HII) in the stress environment (Table 1). HII of $R$. fortunei seedlings was the highest, followed by $R$. mariesii seedlings. HII of $R$. ovatum and $R$. simsii seedlings was lower, 0.25 and 0.275 respectively.

Table 1. Effects of heat stress on the injury index of four Rhododendron species

\begin{tabular}{ccccc}
\hline & $R$. fortunei & $R$. ovatum & $R$. simsii & $R$. mariesii \\
\hline Heat stress & 0.5 & 0.25 & 0.275 & 0.325 \\
Control & 0.2 & 0.075 & 0.075 & 0.225 \\
\hline
\end{tabular}

\section{Lipid peroxidation of cell membrane and change of SOD activity}

SOD enzymes catalyze the dismutation of superoxide into oxygen and hydrogen peroxide, provide the first line of defense against ROS in various subcellular compartments. To estimate the oxidative damage of four Rhododendron seedlings induced by excessive ROS under heat stress, the content of MDA, an important bio-marker of oxidative stress-induced damage (Asada, 1998), was determined. The results showed that MDA content in $R$. fortune $i$ seedlings increased, no significant changes in MDA content in $R$. ovatum, R. simsii and $R$. mariesii leaves were observed (Fig. 2). The result indicated that $R$. fortune $i$ suffered from more serious oxidative damage than other three species. It may be related to the change of SOD activity under heat stress. In our study, we found that heat stress resulted in the decrease of SOD activity in $R$. fortunei seedlings, but increased in $R$. mariesii seedlings. Data analyses showed the promoted effects were significant only in $R$. mariesii seedlings (Fig. 3).

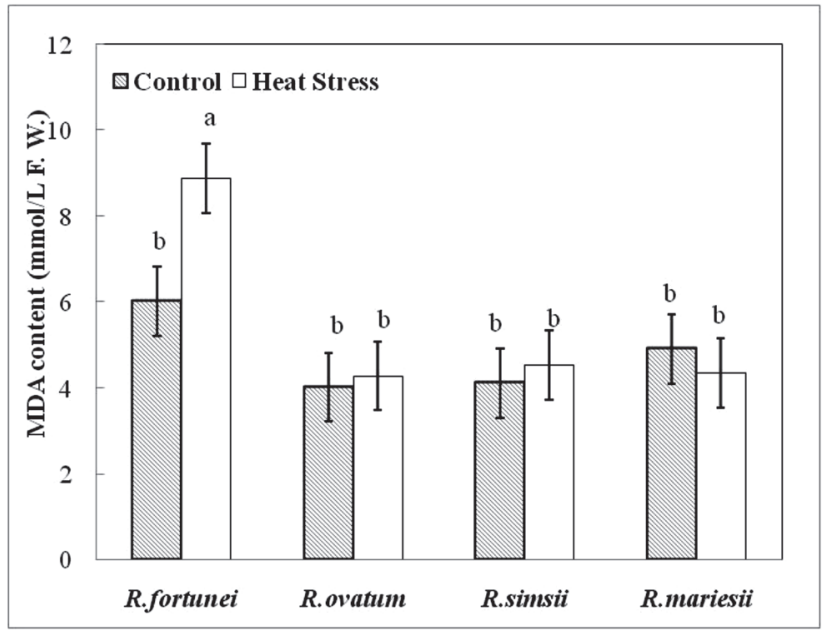

Fig. 2. Changes of MDA content of four Rhododendron species under heat stress. The values presented are the means \pm standard deviations (SD) of three replicates $(n=3)$. The Duncan's multiple range test was applied to compare significant differences between the control and heat stressed seedlings of the four Rhododendron species. Letters a and b indicate significant difference at the $p<5 \%$ level.

\section{Accumulation of proline, solubule sugars and pro-} teins

Proline is known to occur widely in higher plants and normally accumulates in large quantities in response to environmental stresses (Kishor et al., 2005). In the four Rhododendron species, proline content in $R$. simsii seedlings was higher than other three species (Fig. 4). Upon exposure to heat stress, leaf proline content showed a significant increase in $R$. ovatum $(70.5 \%), R$. fortunei (52.4\%), R. simsii (42.2\%) whereas a non-significant increase (8.6\%) was observed in heat-stressed R. mariesii seedlings compared to the control group.

The level of soluble sugars in $R$. fortune $i$ was lower than the level in R. mariesii in control (Fig. 5). After

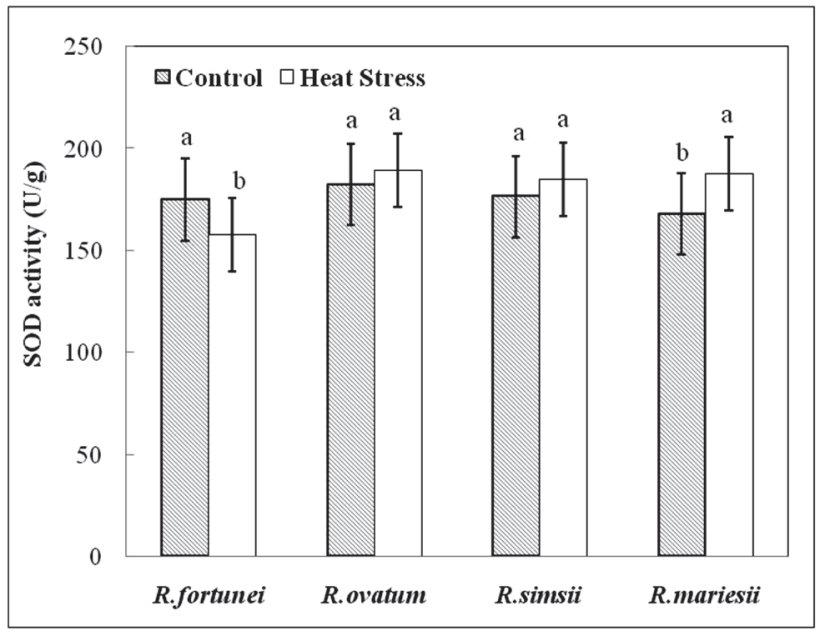

Fig. 3. Changes of SOD activity of four Rhododendron species under heat stress. The values presented are the means \pm standard deviations (SD) of three replicates $(n=3)$. The Duncan's multiple range test was applied to compare significant differences between the control and heat stressed seedlings of the four Rhododendron species. Letters a and $\mathrm{b}$ indicate significant difference at the $p<5 \%$ level.

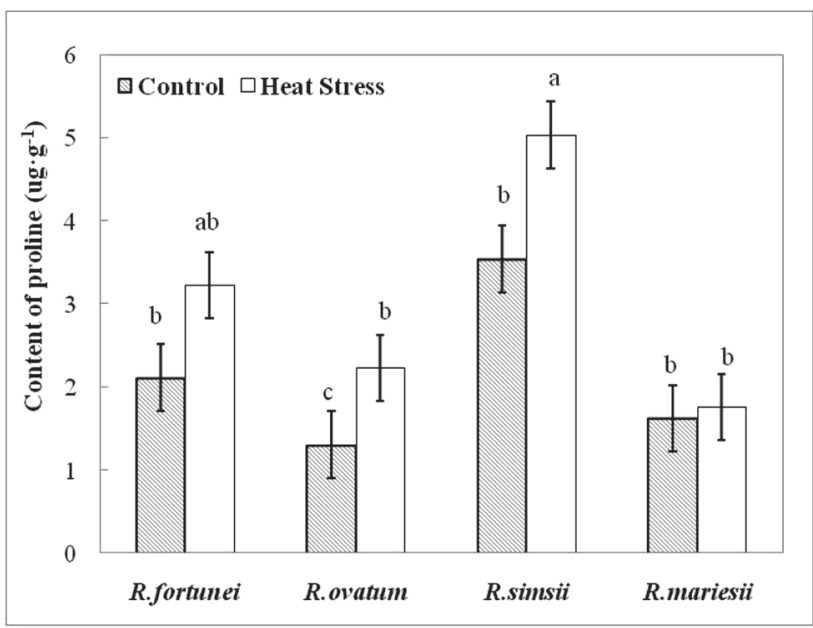

Fig. 4. Changes of proline content of four Rhododendron species under heat stress. The values presented are the means \pm standard deviations (SD) of three replicates $(n=3)$. The Duncan's multiple range test was applied to compare significant differences between the control and heat stressed seedlings of the four Rhododendron species. Letters a and $\mathrm{b}$ indicate significant difference at the $p<5 \%$ level. 


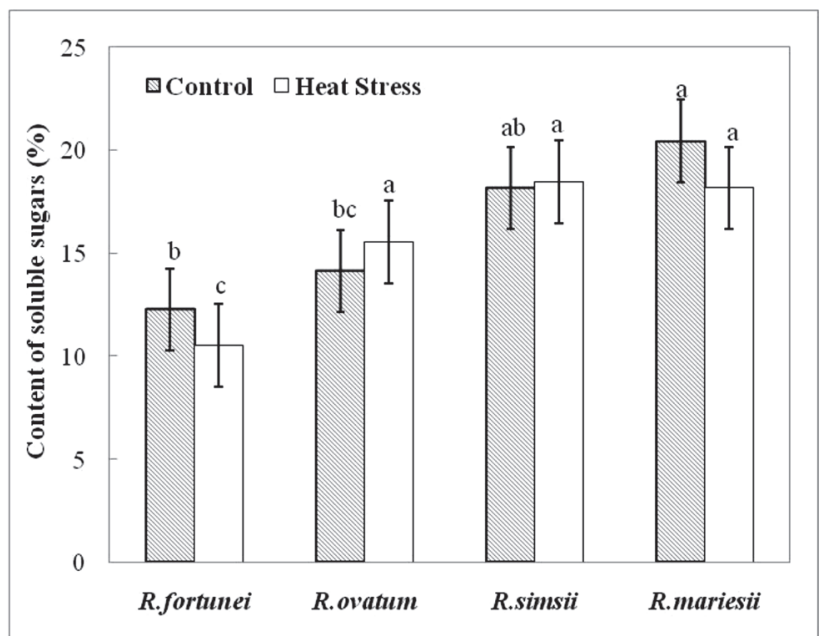

Fig. 5. Changes of content of soluble sugar in four Rhododendron species under heat stress. The values presented are the means \pm standard deviations (SD) of three replicates $(n=$ 3). The Duncan's multiple range test was applied to compare significant differences between the control and heat stressed seedlings of the four Rhododendron species. Letters $\mathrm{a}$ and $\mathrm{b}$ indicate significant difference at the $p<$ $5 \%$ level.

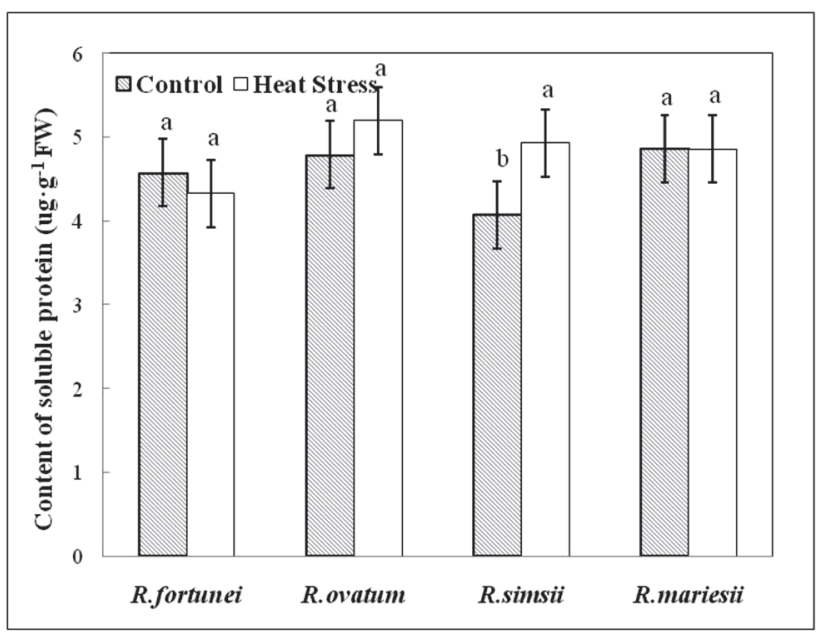

Fig. 6. Changes in content of soluble protein in four Rhododendron species under heat stress. The values presented are the means \pm standard deviations (SD) of three replicates $(n=3)$. The Duncan's multiple range test was applied to compare significant differences between the control and heat stressed seedlings of the four Rhododendron species. Letters a and $\mathrm{b}$ indicate significant difference at the $p<5 \%$ level.

Table 2. Photosynthetic indices of Rhododendron leaves under heat stress

\begin{tabular}{|c|c|c|c|c|c|}
\hline & Treatment & R. fortunei & R. ovatum & R. simsii & R. mariesii \\
\hline $\mathrm{P}_{\mathrm{N}}\left(\mu \mathrm{mol} / \mathrm{m}^{-2} \cdot \mathrm{s}^{-1}\right)$ & HS & $0.853 \pm 0.05$ & $2.827 \pm 0.2$ & $2.162 \pm 0.14$ & $2.489 \pm 0.14$ \\
\hline \multirow[t]{2}{*}{$\mathrm{Ci}\left(\mathrm{mmol} / \mathrm{m}^{-2} \cdot \mathrm{s}^{-1}\right)$} & Control & $318.9 \pm 10.05$ & $283.445 \pm 17.86$ & $249.679 \pm 11.13$ & $256.91 \quad \pm 14.87$ \\
\hline & HS & $359.67 \pm 12.37$ & $296.852 \pm 18.87$ & $262.251 \pm 16.83$ & $272.438 \pm 9.35$ \\
\hline Gs $\left(\mu \mathrm{mol} / \mathrm{m}^{-2} \cdot \mathrm{s}^{-1}\right)$ & HS & $0.063 \pm 0.002$ & $0.049 \pm 0.006$ & $0.033 \pm 0.006$ & $0.035 \pm 0.007$ \\
\hline \multirow[t]{2}{*}{$\operatorname{Tr}\left(\mathrm{mmol} / \mathrm{m}^{-2} \cdot \mathrm{s}^{-1}\right)$} & Control & $1.577 \pm 0.14$ & $2.017 \pm 0.04$ & $1.993 \pm 0.05$ & $1.711 \pm 0.13$ \\
\hline & HS & $1.579 \pm 0.1$ & $1.652 \pm 0.09$ & $1.341 \pm 0.07$ & $1.286 \pm 0.14$ \\
\hline
\end{tabular}

${ }^{\mathrm{z}}$ the means \pm standard deviation

heat stress the decrease of soluble sugars in $R$. fortune $i$ was observed. Heat stress did not affect the content of soluble sugars in $R$. simsii seedlings, but $R$. ovatum accumulated more soluble sugars than the responding control plants.

As shown in Fig. 6, the content of soluble proteins in $R$. simsii leaves was the lowest in control temperature, but only $R$. simsii leaves after heat stress appeared the significant increase in the content of soluble proteins. The content in $R$. fortunei and $R$. mariesii leaves decreased by $5.42 \%$ and $0.13 \%$, respectively.

\section{Effects of heat stress on photosynthesis indices}

Changes of photosynthetic indices including $P_{N}$, Gs, $\mathrm{Ci}$ and $\mathrm{Tr}$ were measured $1 \mathrm{~d}$ (Table 2) and $5 \mathrm{~d}$ (data not shown) after heat stress. One day after heat stress $P_{N}$ rates for R. simsii, R. ovatum, R. mariesii and $R$. fortunei were $3.6,3.5,3.4$ and $2.2 \mu \mathrm{mol} \cdot \mathrm{m}-2 \cdot \mathrm{s}-1$ respectively at control temperature. $P_{N}$ rates for four species were decreased at different levels due to heat stress, but reduction proportion of $P_{N}$ for $R$. fortunei was $61.5 \%$, and most significantly, the other three species including $R$. simsii, R. ovatum and R. mariesii decreased by $39.6 \%, 18.3 \%$ and $26.7 \%$ respectively.

High temperature decreased Gs of $R$. simsii, $R$. ovatum and $R$. mariesii, $\mathrm{Tr}$ of these three species was inhibited. Although Gs of $R$. fortunei increased by 7.34\% $1 \mathrm{~d}$ after heat stress, however, its transpiration rate did not change compared to control plants. Heat stress increased internal leaf $\mathrm{CO}_{2}$ concentrations of four species, and the increase in $R$. fortune $i$ was most significant, its increasing rate was $12.79 \%$.

\section{DISCUSSION}

According to heat injury indexes and symptom of four $R$. species (Table 1and Fig. 1), R. fortune $i$ is the most susceptible for heat stress, $R$. simsii and $R$. ovatum have higher heat tolerance than $R$. mariesii. MDA level in R. simsii, R. ovatum and R. mariesii seedlings 
did not change under heat stress, however, significantly decreased in $R$. fortunei seedlings due to heat stress (Fig. 2), which indicated high temperature resulted in the increase of ROS level (Nagesh and Devaraj, 2008; Kumar et al., 2011) and serious oxidative damage of cell membrane in $R$. fortunei seedlings (Moller et al., 2007). Heat-resistant Rhododendron species keep more stable anatomical structure under heat stress than heat-sensitive species (Gu et al., 2016; Shen et al., 2017).

After heat stress, the increase of SOD activity of three heat-tolerant species was observed, only SOD activity of $R$. fortunei seedlings decreased (Fig. 3). SOD functions as the first defense against ROS, whose activity contributes to the scavenging of the excessive ROS and increase the stress tolerance. The decrease of SOD activity in $R$. fortunei seedlings should be directly related to the accumulation of MDA and serious cell membrane damage of $R$. fortunei seedlings. The important role of antioxidant enzymes in response of rhododendron seedlings to high temperature have also been reported by Shen et al. (2017). So genetic transformation approach by adjusting ROS scavenging systems of rhododendrons can enhance oxidative stress tolerance. Similar researches have been reported in other plants. Overexpression of $\mathrm{Cu} / \mathrm{Zn}$ SOD and APX induced thermotolerance to $42^{\circ} \mathrm{C}$ in transgenic potato plants (Kim et al., 2010). Overexpression of SOD and glutathione reductase (GR), were reported to result in an increased resistance to drought, ozone, low temperature, and high light stress (McKersie et al., 2000; Panchuk et al., 2002; Van Camp et al., 1996).

In essence, accumulation and adjustment of compatible solutes are an important adaptation toward heatstress tolerance by plants. In this study, proline level increased in the four Rhododendron species after heat stress (Fig. 4), and the increase was more significant in heat-tolerant species. Accumulation of proline under stress in many plant species has been correlated with stress tolerance (Kaushal et al., 2011; Wilson et al., 2014), and its concentration has been shown to be generally higher in stress-tolerance plants than in stresssensitive plants (Ashraf and Foolad, 2007; Yuan et al., 2011; Chen et al., 2012). But in the present study, the further data analysis indicated there was not significant correlation between proline accumulation and heat tolerance of rhododendron seedlings, maybe because heatsensitive species such as $R$. fortunei accumulated more proline than $R$. ovatum and $R$. mariesii in control and stress temperature (data analysis not shown). Lv et al. (2011) indicated that proline accumulation under heat stress decreases the thermotolerance, probably by increasing ROS production via the Pro/P5C cycle and inhibition of ABA and ethylene biosynthesis.

The accumulation of soluble sugars induced by heat stress was investigated only in heat-tolerant Rhododendron species including $R$. simsii and $R$. ovatum (Fig. 5), their content in $R$. fortunei seedlings decreased obviously after heat stress. And the data analysis showed that heat tolerance of Rhododendron seedlings was closely related to the level of soluble sug- ars. Similarly, accumulation of soluble sugars under heat stress has been reported in sugarcane, which entails great implications for heat tolerance (Wahid and Close 2007). High temperature caused the increase of soluble leaf protein in heat-tolerant Rhododendron species (Fig. 6). This increase in total soluble proteins under heat stress may be the induction of stress proteins such as dehydrin proteins (DHNs) and heat shock proteins (HSPs). Further, as suggested by Wahid and Close (2007), most of stress-induced proteins are soluble in water and therefore contributes to stress tolerance presumably via hydration of cellular structures.

$\mathrm{P}_{\mathrm{N}}$ was inhibited in the four $R$. species (Table 2). Ranney et al. (1995) suggested that the decrease of $P_{N}$ was due to the combination of stomatal and nonstomatal factors. In the present study, heat stress at $42^{\circ} \mathrm{C} / 30^{\circ} \mathrm{C}$ (day/night) for $24 \mathrm{~h}$ resulted in the decrease of Gs and the increase of $\mathrm{Ci}$ in $R$. mariesii, $R$. simsii and $R$. ovatum seedlings, which indicated the decline in photosynthesis under heat stress appeared to mainly result from nonstomatal factors. Gs and $\mathrm{P}_{\mathrm{N}}$ are inhibited by moderate heat stress in many plant species due to the decreases in the activation state of rubisco (CraftsBrander and Salvucci, 2002; Morales et al., 2003). Heat stress resulted in the damage of cell membrane of $R$. fortunei seriously (Fig. 2), which may be main reason of the decrease of $\mathrm{P}_{\mathrm{N}}$. It has been reported that the damage of the structural organization of thylakoids may be main reason of the decrease of $\mathrm{P}_{\mathrm{N}}$ under stresses (Karim et al., 1997 and Vani et al., 2001).

\section{AUTHOR CONTRIBUTIONS}

Xing-Ming GENG carried out substantial contribution to the concept and design on this paper. Qiu-Yu YANG and Yuan YUE carried out analysis and interpretation of the data. Yukio OZAKI verified the data. All authors contributed in editing the manuscript and approved the final version.

\section{ACKNOWLEDGMENTS}

This work was supported by the Priority Academic Program Development of Jiangsu Higher Education Institutions (PAPD).

\section{REFERENCES}

Adams III, W. W., C. R. Zarter, V. Ebbert and B. Demmig-Adams 2004 Photoprotective strategies of overwintering evergreens. BioScience, 54: 41-49

Apel, K. and H. Hirt 2004 Reactive oxygen species: metabolism, oxidative stress, and signal transduction. Annu. Rev. Plant Biol., 55: 373-99

Asada, K., T. Endo, J. Mano and C. Miyake 1998 Molecular mechanisms for relaxation of and protection from light stress. In "Stress Responses of Photosynthetic Organisms", ed. by K Satoh and N. Murata, Elsevier Science BV, Amsterdam, pp. 37-52

Ashraf, M. and M. R. Foolad 2007 Roles of glycine betaine and proline in improving plant abiotic stress resistance. Environ. Exp. Bot., 59: 206-216 
Bjorkman, O., M. R. Dadger and P. A. Armond 1980 Response and adaptation to high temperatures. In "Adaptation of plants to water and high temperature stress", ed. by N. C. Turner and P. J. Kramer, John Wiley and Sons, New York, pp. 233-249

Bradford, M. M. 1976 A rapid and sensitive method for quantitation of microgram quantities of protein utilizing the principle of protein-dye binding. Anal. Biochem., 72: 248-254

Chamberlain, D., R. Hyam, G. Argent, G. Fairweather and K. S. Walter 1996 The genus Rhododendron: its classification and synonymy. Royal Botanic Garden Edinburgh.

Chen, W. R., W. A. Cen, L. Chen, L. L. Di, Y.Q. Li and W. D. Guo 2012 Differential sensitivity of four highbush blueberry (Vaccinium corymbosum L.) cultivars to heat stress. Pak. J. Bot., 44: 853-860

Crafts-Brander, C. and M. E. Salvucci 2002 Sensitivity to photosynthesis in the $\mathrm{C}_{4}$ plant, maize to heat stress. Plant Cell, $\mathbf{1 2}$ : $54-68$

Cruz de Carvalho, M. H. 2008 Drought stress and reactive oxygen species: production, scavenging and signaling. Plant Signal. Behavi., 3: 156-165

Geng, X. M., J. Liu, J. G. Lu, F. R. Hu and H. Okubo 2009 Effects of cold storage and different pulsing treatments on postharvest quality of cut OT lily 'Mantissa' flowers. J. Fac. Agr., Kyushu Univ., 54: 41-45

Gu, K., X. M. Geng, Y. Yue and Y. Ozaki 2016 Contribution of keeping more stable anatomical structure under high temperature to heat resistance of Rhododendron seedlings. J. Fac. Agr., Kyushu Univ., 61: 273-279

Kai, H., K. Hirashima, O. Matsuda, H. Ikegami, T. Winkelmann, T. Nakahara and K. Iba, 2012. Thermotolerant cyclamen with reduced acrolein and methyl vinyl ketone. J. Exp. Bot., 63: $4143-4150$

Karim, M. A., Y. Fracheboud and P. Stamp 1997 Heat tolerance of maize with reference of some physiological characteristics. Ann. Bangladesh Agri., 7: 27-33

Kaushal, N., K. Gupta, K. Bhandhari, S. Kumar, P. Thakur and H. Nayyar 2011 Proline induces heat tolerance in chickpea (Cicer arietinum L.) plants by protecting vital enzymes of carbon and antioxidative metabolism. Physiol. Mol. Biol. Plant., 17: 203-213

Kim, M. D., Y. H. Kim, S. Y. Kwon, D. J. Yun, S. S. Kwak and H. S. Lee 2010 Enhanced tolerance to methyl viologen-induced oxidative stress and high temperature in transgenic potato plants overexpressing the CuZnSOD, APX and NDPK2 genes. Physiol. Plant., 140: 153-162

Kishor, P. B. K., S. Sangam, R. N. Amrutha, P. S. Laxmi, K. R. Naidu, K. R. S. S. Rao, S. Rao, K. J. Reddy, P. Theriappan and N. Sreenivasulu 2005 Regulation of proline biosynthesis, degradation, uptake and transport in higher plants: its implications in plant growth and abiotic stress tolerance. Curr. Sci., 88: 424438

Kumar, S., R. Kaur, N. Kaur, K. Bhandhari, N. Kaushal, K. Gupta and H. Nayyar 2011 Heat-stress induced inhibition in growth and chlorosis in mungbean (Phaseolus aureus Roxb.) is partly mitigated by ascorbic acid application and is related to reduction in oxidative stress. Acta Physiol. Plant., 33: 2091-2101

Larkindale, J. and M. R. Knight 2002 Protection against heat stress induced oxidative damage in Arabidopsis involves calcium, abscisic acid, ethylene, and salicylic acid. Plant Physiol., 128: $682-695$

Lv, W. T., B. Lin, M. Zhang and X. J. Hua 2011 Proline accumulation is inhibitory to Arabidopsis seedlings during heat stress. Plant Physiol., 156: 1921-1933

McKersie, B. D., J. Murnaghan, K. S. Jones and S. R. Bowley 2000 Iron-superoxide dismutase expression in transgenic alfalfa increases winter survival without a detectable increase in photo- synthetic oxidative stress tolerance. Plant Physiol., 122: 14271437

Mittler, R., S. Vanderauwera, M. Gollery, F. Van Breusegem 2004 Reactive oxygen gene network of plants. Trends Plant Sci., 19 : $490-498$

Mittler, R. 2017 ROS are good! Trends Plant Sci., 22: 11-19

Moller, I. M., P. E. Jensen and A. Hansson, 2007. Oxidative modifications to cellular components in plants. Annu. Rev. Plant Biol., 58: 459-481

Morales, D., P. Rodríguez, J. Dellámico, E. Nicolás, A. Torrecillas and M.J. Sánchez-Blanco 2003 High-temperature preconditioning and thermal shock imposition affects water relations, gas exchange and root hydraulic conductivity in tomato. Biol. Plant., 47: 203-208

Murata, N., S. Takahashi, Y. Nishiyama and S. I. Allakhverdiev 2007 Photoinhibition of photosystem II under environmental stress. Biochimica et Biophysica Acta, 1767: 414-421

Nagesh, B. R. and V. R. Devaraj 2008 High temperature and salt stress response in French bean (Phaseolus vulgaris). Aus. J. Crop Sci., 2: 40-48

Panchuk, I. I., R. A. Volkov and F. Schoffl 2002 Heat stress-and heat shock transcription factor-dependent expression and activity of ascorbate peroxidase in Arabidopsis. Plant Physiol., 129: $838-853$

Ranney, T. G., F. A. Blazich and S. L. Warren 1995 Heat tolerance of selected species and populations of Rhododendron. $J$. Amer. Soc. Hort. Sci., 120: 423-428

Rasheed, R., A. Wahid, M. Farooq, I. Hussain and S. M. A. Basra 2011 Role of proline and glycinebetaine pretreatments in improving heat tolerance of sprouting sugarcane (Saccharum sp.) buds. Plant Growth Regul., 65: 35-45

Rizhsky, L., H. Liang, J. Shuman, V. Shulaev, S. Davletova and R. Mittler 2004 When defense pathways collide. The response of Arabidopsis to a combination of drought and heat stress. Plant Physiol., 134: 1683-1696

Santarius, K. A. 1973 The protective effect of sugars on chloroplast membranes during temperature and water stress and its relationship to frost, desiccation and heat resistance. Planta, 113: $105-114$

Shen, H. F., B. Zhao, J. J. Xu, W. Liang, W. M. Huang and H. H. Li 2017 Effects of heat stress on changes in physiology and anatomy in two cultivars of Rhododendron. South Afr. J. Bot., 112 $338-345$

Takahashi, S. and N. Murata 2008 How do environmental stresses accelerate photoinhibition? Trends Plant Sci., 13: 178-182

Van Camp, W., K. Capiau, M. Van Montagu, D. Inze and L. Slooten 1996 Enhancement of oxidative stress tolerance in transgenic tobacco plants overproducing Fe-superoxide dismutase in chloroplasts. Plant Physiol., 112: 1703-1714

Vani, B., P. P. Saradhi and P. Mohanty 2001 Alteration in chloroplast structure and thylakoid membrane composition due to in vivo heat treatment of rice seedlings: correlation with the functional changes. J. Plant Physiol., 158: 583-592

Wahid, A. and T. J. Close 2007 Expression of dehydrins under heat stress and their relationship with water relations of sugarcane leaves. Biol. Plant., 51: 104-109

Wahid, A., S. Gelani, M. Ashraf and M. R. Foolad 2007 Heat tolerance in plants: An overview. Environ. Exp. Bot., 61: 199-223

Wilson, R. A., M. K. Sangha, S. S. Banga, A. K. Atwal and S. Gupta, 2014. Heat stress tolerance in relation to oxidative stress and antioxidants in Brassica juncea. J. Environ. Biol., 35: 383387

Yuan, Y., H. M. Qian, Y. D. Yu, F. Q. Lian and D. Q. Tang 2011 Thermotolerance and antioxidant response induced by heat acclimation in Freesia seedlings. Acta Physiol. Plant., 33 1001-1009 